\title{
Groundwater Quality Studies Using Geographic Information System in Dharmapuri District, Tamil Nadu, India
}

\author{
V. Rajendran ${ }^{1}$, R. Venkatasubramani ${ }^{2}$, M. Suresh ${ }^{3}$ \\ Department of Civil Engineering, Muthayammal Engineering College, Rasipuram-637408. \\ rajcivil2009@yahoo.com \\ Department of Civil Engineering ,Dr.Mahalingam College of Engineering and Technology, Pollachi-642003. \\ rvs_vlb@yahoo.com \\ Department of Civil Engineering, Jayalakshmi Institute of Technology, Thoppur - 636352 \\ watersuresh@gmail.com \\ ${ }^{1}$ Corresponding author mail id: rajcivil2009@yahoo.com
}

\begin{abstract}
This scientific report deals with the quality of groundwater for drinking purpose in the hard-rock aquifer of Dharmapuri district, Tamil Nadu South India. 135 Groundwater samples were collected based on the equal grid method and groundwater quality was assessed. Geographically the aerial extent of the study area is plain portion $3313.15 \mathrm{Sq} . \mathrm{Km}$ and Hill and forest $1346.25 \mathrm{Sq} . \mathrm{Km}$. groundwater samples was analyzed in various physicochemical parameters and major ion chemistry like pH, EC, TDS, Ca2+, Mg2+, Na+, K+, HCO3-, Cl-, SO42-, NO3- and F-. Based on the analytical results, to prepared spatial distribution maps with help of WHO standard. ArcGIS was employed. Attributes were linked and spatial interpolation tool was used. IDW technique was followed for raster and vector mapping. Finally integration analysis was carried out to locate the worst quality zone. Based on the analysis, most of the samples are suitable for drinking. The final integrated map (Drinking quality) reveals that for suitable for drinking and domestic purpose. "Not permissible" water quality zone cover about area $2467.09 \mathrm{sq}$. km respectively. While "Maximum allowable" water quality zone cover an area of $836.87 \mathrm{sq}$. km. The "Most desirable" water quality zone an area $9.19 \mathrm{sq} . \mathrm{km}$ for drinking and domestic purposes.
\end{abstract}

\section{Keywords}

hard-rock aquifer, spatial distribution map, interpolation, overlay.

\section{Academic Discipline And Sub-Disciplines}

Water Resources Engineering

\section{SUBJECT CLASSIFICATION}

Water quality

\section{TYPE (METHOD/APPROACH)}

Spatial approach

\section{INTRODUCTION}

Assessment of groundwater quality is as important as the quantity, in many groundwater studies. Groundwater physico-chemical ions in the form of solution, the type and concentration of these elements depends upon the surface and sub-surface environment, rate of groundwater movements and the source of groundwater. Contamination of water is mainly due to the anthropogenic activity and effluents that are discharged as waste or sewage from residences and industries, and so on. The most important source of pollutants that deteriorate and decrease the quality of groundwater are the discharge of wastes from industries and effluents from residence.

A large number of hydrogeochemical investigations has been carried out by different researchers in various parts of India (Singh, 1992; Aravindan et al. 2004; SubbaRao, 2006; Kumar et al., 2007; Adhikary et al., 2012; Gurugnanam et al. 2009 Aravindan et al. 2010; Prasanna et al. 2010; Tiwari AK and Singh AK 2014; Krishna Kumar et al. 2015; Gupta et al. 2016).

\section{STUDY AREA DESCRIPTION}

Dharmapuri district is located (Fig. 1) between latitudes N 11045'49.25” to 12030'.54.17" and longitudes E 77040'38.026" to $78044^{\prime} 49.075$ ". The total geographical area of the district is $4659.40 \mathrm{Sq}$.Km (3.46 \% of Tamil Nadu geographical area). Hill and forest area is occupied in $1346.25 \mathrm{Sq} . \mathrm{Km}$ and aerial extended plain area is $3313.15 \mathrm{Sq} . \mathrm{Km}$. Dharmapuri district is endowed with sizeable reserves of granite. High quality black granite is available in Pennagaram, Palacode and Harur blocks. Quartz minerals are presented in Kendiganapalli Village of Pennegaram Taluk. Another high economic valuable mineral is Molibdinum, which is well-known as a good conductor. It is available in Harur.

Dharmapuri district came into existence from October 10, 1965. The district population is 1.507 million (2011 Censes). It is surrounded on the north side occurred Krishnagiri District, Eastern side by Tiruvannamalai district and Vilupuram Districts, on the southern side in Salem District, the western part occurred by Karnataka's Chamarajanagar district. The whole 

district is surrounds by hills and forests. The terrain of dharmapuri district is located on geographically important area in south India.

Dharmapuri district are consist of seven revenue Taluks as Dharmapuri, Harur, Karimangalam, Nallampalli, Palacode, Pappireddipatti, Pennagaram. The Dharmapuri economy is mainly agrarian in nature. The district economy is mainly agrarian in nature and nearly $70 \%$ of the workforce is dependent on agriculture and allied activities. The district is one among most backward and drought prone area in the state. The climate of the Dharmapuri district is generally warm. The normal annual rainfall over the district varies. The normal annual rainfall over the district varies from about 760 to 910 $\mathrm{mm}$. The normal onset and withdrawal of SW monsoon is June first week and September fourth week, and that of NW monsoon is October first week and December third week respectively.

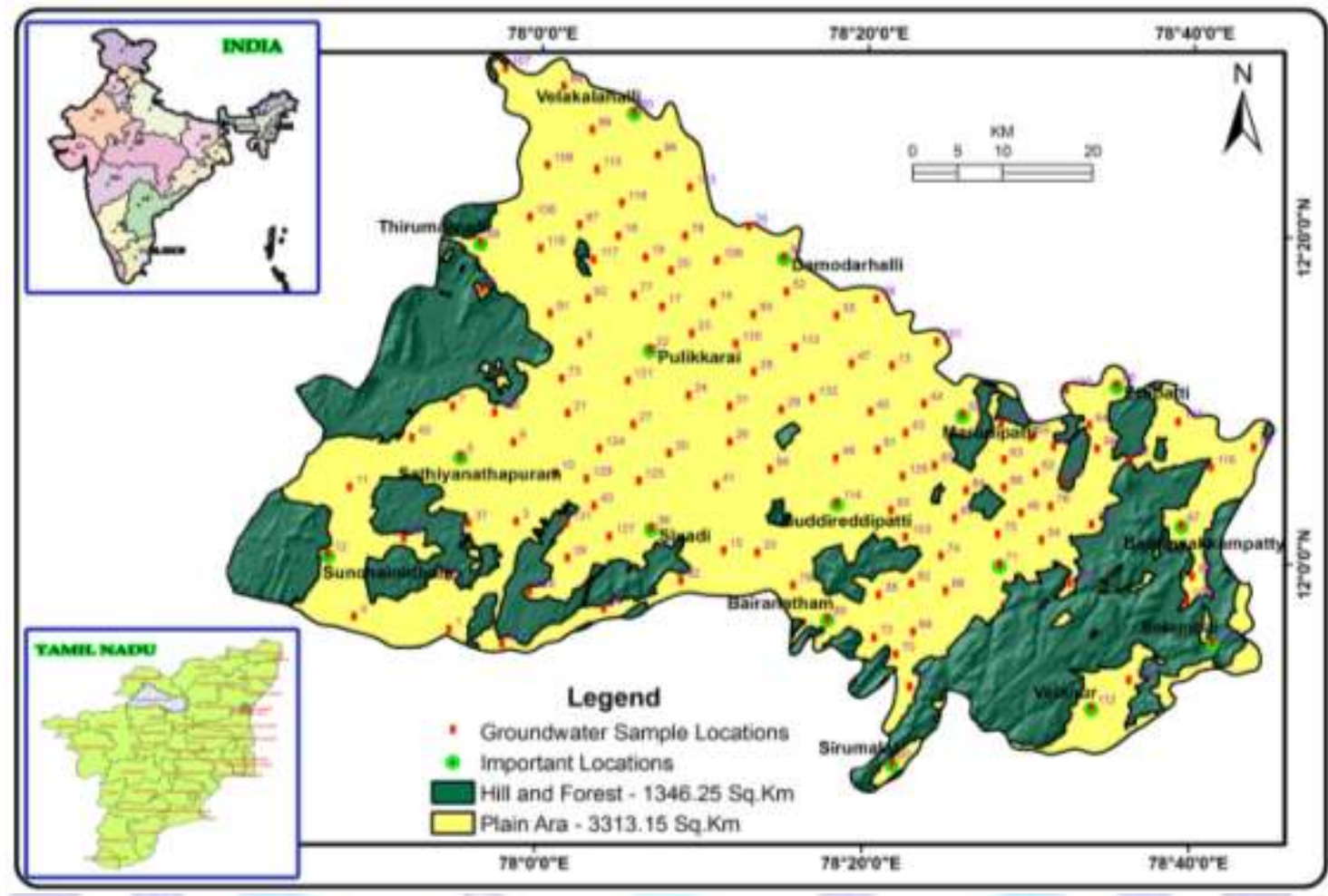

Fig. 1 Study Area with Groundwater Sample Locations Map

\section{METHODOLOGY}

The groundwater samples from 132 locations were collected during post-monsoon season (May 2015) from dug wells and bore wells. These wells are extensively used for drinking and irrigation purposes. The locations of observation wells are shown in the Fig. 1. The parameters of groundwater such as $\mathrm{pH}$ and electrical conductivity were measured immediately after collection by using Elico $\mathrm{pH}$ meter and conductivity meter. The concentration of calcium (Ca2+) and Magnesium (Mg2+) ions was determined by EDTA method, and chloride was determined by silver nitrate (Volgel 1968). The CO3 and $\mathrm{HCO} 3$ were estimated with standard sulphuric acid and sulphate was analyzed by precipitating $\mathrm{BaSO} 4$ from $\mathrm{BaCl} 2$ method. The Sodium $(\mathrm{Na}+)$ and Potasium $(\mathrm{K}+)$ ions and were determined by Elico flame photometer (APHA 1995). The accuracy of the chemical analyses was verified by calculating ion-balance errors; where, the errors were generally around 8-10\%. The base map was prepared using Survey of India toposheet on 1:50,000 scale. The various attributes were added and analyzed in ArcGIS software using the spatial analysis tools and interpolation maps were prepared for water quality parameters. The spatial distribution maps of various groundwater quality parameters through GIS.

\section{RESULTS AND DISCUSSION}

Understanding that groundwater quality an important as it is the main factor determining its suitability for drinking purposes (Subramani et al. 2005). The physical and chemical parameters of groundwater samples including statistical measures such as minimum, maximum, average, median and mode are given in Table.1. The $\mathrm{pH}$ values of groundwater ranges from 6.95 to 8.21 indicating alkaline nature with an average value of 7.44. As per the World Health Organization standard (WHO 1996), all the samples fall within the permissible limit (6.5 to 8.5) for human consumption based on the $\mathrm{pH}$ value. The electrical conductivity of the samples varies from 363 to $5990 \mu \mathrm{Scm}-1$ with an average value $2113.25 \mu \mathrm{Scm}-1$. The TDS value varies from 152 to $3362 \mathrm{mg} / \mathrm{l}$ during the post-monsoon season. The TDS values of the total well locations 43 are found to be high concentration respectively. TDS spatial distribution map (Fig. 2) reveals that $1397.28 \mathrm{Sq} . \mathrm{Km}$ areas are classified as not permissible limit. 
Table 1 Statistical Analysis Data with WHO Limiting Values and Exceeding Samples

\begin{tabular}{|c|c|c|c|c|c|c|c|c|}
\hline \multirow{2}{*}{$\begin{array}{l}\text { Paramet } \\
\text { ers }\end{array}$} & \multicolumn{2}{|c|}{$\begin{array}{l}\text { WHO international } \\
\text { standard }\end{array}$} & \multirow{2}{*}{$\begin{array}{c}\text { No. of wells } \\
\text { exceeding } \\
\text { permissible } \\
\text { limits }\end{array}$} & \multirow{2}{*}{ Mean } & \multirow{2}{*}{ Minimum } & \multirow{2}{*}{ Maximum } & \multirow{2}{*}{ Std.Dev. } & \multirow{2}{*}{ Undesirable effect } \\
\hline & \begin{tabular}{|l|} 
Most \\
desirable \\
limit
\end{tabular} & $\begin{array}{l}\text { Maximum } \\
\text { allowable } \\
\text { limit }\end{array}$ & & & & & & \\
\hline $\mathrm{pH}$ & $6.5-8.5$ & - & Nil & 7.44 & 6.95 & 8.21 & 0.24 & Taste \\
\hline EC & 1500 & - & 73 & 2113.25 & 363.00 & 5990.00 & 1254.69 & $\begin{array}{ll}\text { Gastro } & \text {-intestinal } \\
\text { irritation } & \end{array}$ \\
\hline TDS & 500 & 1,500 & 43 & 1479.18 & 254.10 & 4193.00 & 878.32 & $\begin{array}{ll}\text { Gastro } & \text {-intestinal } \\
\text { irritation } & \end{array}$ \\
\hline $\mathrm{TH}$ & 100 & 500 & 43 & 425.53 & 76.00 & 968.00 & 239.45 & Scale Formation \\
\hline $\mathrm{Na}^{+}$ & - & 200 & 66 & 265.39 & 47.00 & 780.00 & 160.76 & - \\
\hline $\mathrm{Ca}^{2+}$ & 75 & 200 & 3 & 98.16 & 24.80 & 209.60 & 48.21 & Scale Formation \\
\hline $\mathrm{Mg}^{2+}$ & 50 & 150 & Nil & 43.20 & 3 & 106.56 & 28.73 & scale romation \\
\hline $\bar{K}$ & 10 & - & 123 & 32.10 & 2.00 & 90.00 & 20.61 & - \\
\hline $\mathrm{Fe}$ & 0.3 & - & 2 & 0.02 & 0.00 & 1.60 & 0.16 & \\
\hline $\mathrm{Cl}^{-}$ & 200 & 600 & 16 & 339.45 & 56.00 & 1124.00 & 221.09 & Salty taste \\
\hline $\mathrm{NO}_{3}^{-}$ & 45 & - & 4 & 20.69 & 4.00 & 60.00 & 11.68 & $\begin{array}{l}\text { Blue Baby or } \\
\text { Methamoglobanemi } \\
\text { a }\end{array}$ \\
\hline $\mathrm{SO}_{4}{ }^{2-}$ & 200 & 400 & 25 & 132 & 250.23 & 40.00 & 776.00 & Laxative effect \\
\hline $\mathrm{F}^{-}$ & - & 1.5 & 40 & 1.10 & 0.00 & 2.80 & 0.78 & Fluorosis \\
\hline
\end{tabular}

The value of calcium varies during post-monsoon is 24.80 to $209.60 \mathrm{mg} / \mathrm{l}$, with an average value of $98.16 \mathrm{mg} / \mathrm{l}$. All the samples are within limiting value except 3 samples as per the WHO limit. Ca spatial distribution map (Fig. 3) reveals that $0.79 \mathrm{Sq} . \mathrm{Km}$ areas are classified as not permissible limit. The value of sodium varies from 47 to $780 \mathrm{mg} / \mathrm{l}$, with a mean value of $265.39 \mathrm{mg} / \mathrm{l}$ during this season. A higher amount of sodium salts affect the soil structure, soil permeability and create toxic condition for plants and those sensitive to sodium (Pradeep, 1998). Na spatial distribution map (Fig. 4) reveals that $2380.49 \mathrm{Sq} . \mathrm{Km}$ areas are classified as not permissible limit. The value of potassium varies from 2 to $90 \mathrm{mg} / \mathrm{l}$ and average value $32.10 \mathrm{mg} / \mathrm{l}$ respectively. Potassium, generally being non-water soluble element contains compounds. The hydroxides and nitrate compounds of potassium are said to be the most reactive basic chemical compounds. K spatial distribution map (Fig. 5) reveals that more are less entire study areas are classified as not permissible limit. 


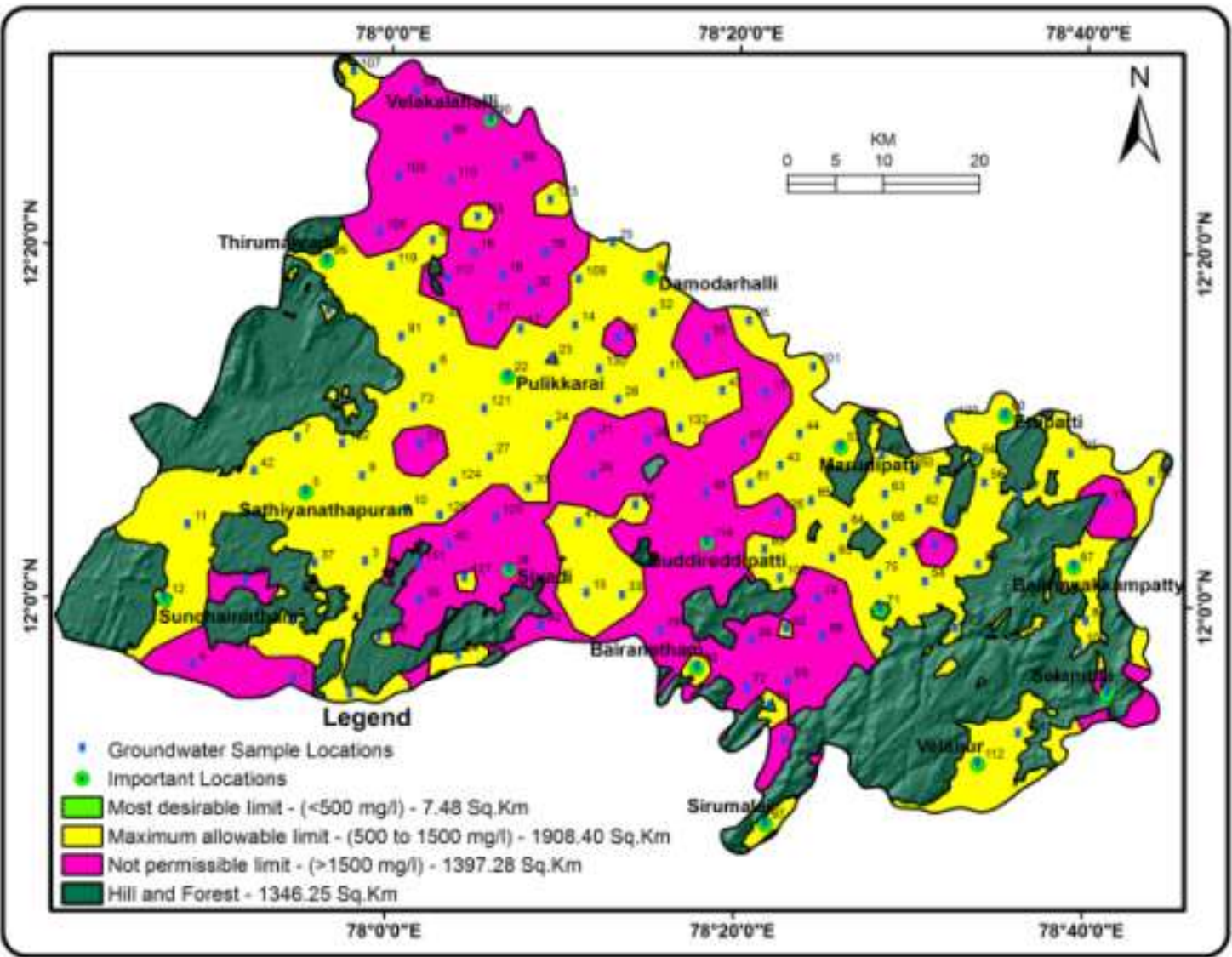

Fig. 2 TDS Spatial Distribution Map

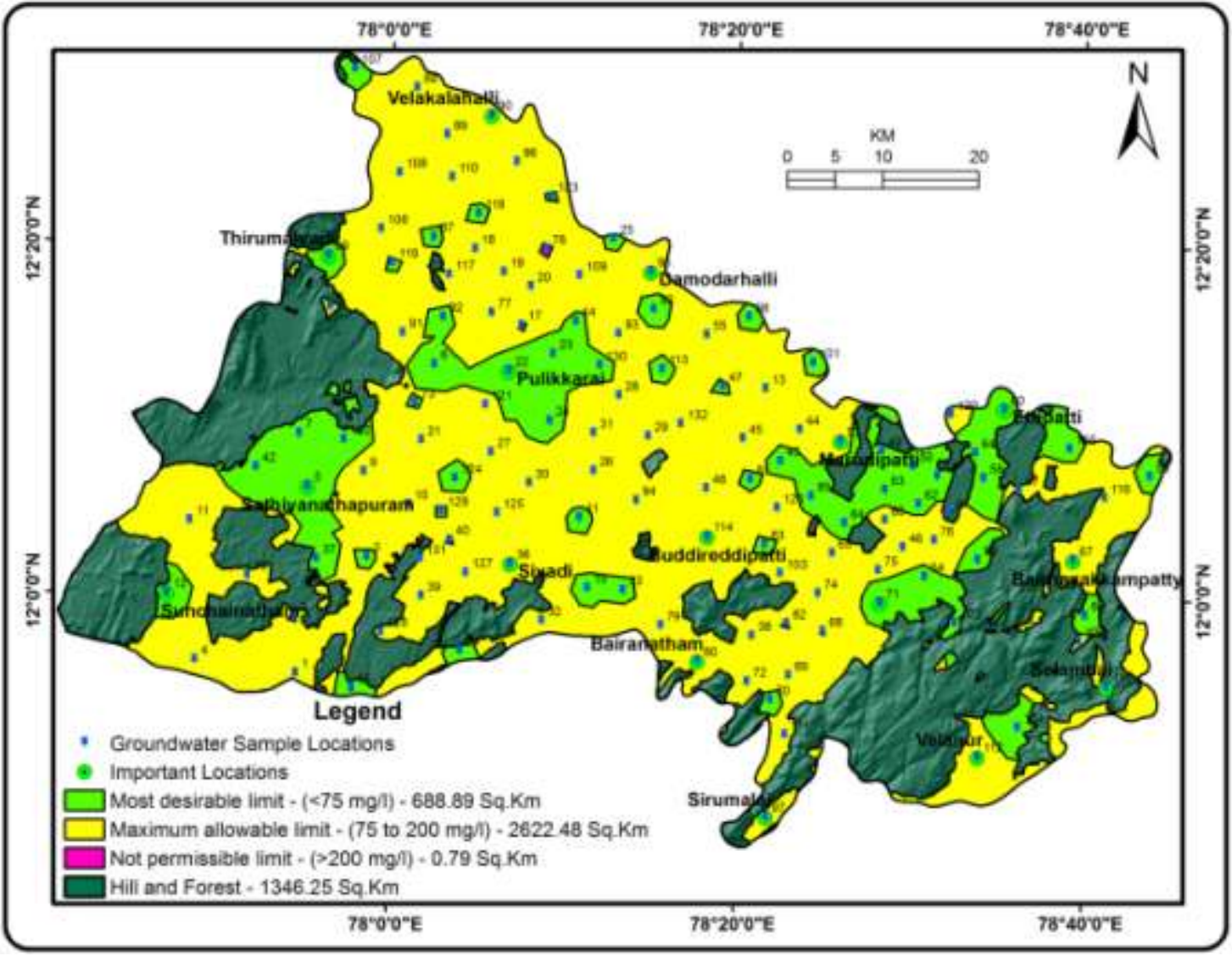

Fig. 3 Ca Spatial Distribution Map

4352 | P a g e 
ISSN $2321-807 x$

Volume $12 \mathrm{Number} 9$

Journal of Advances in Chemistry

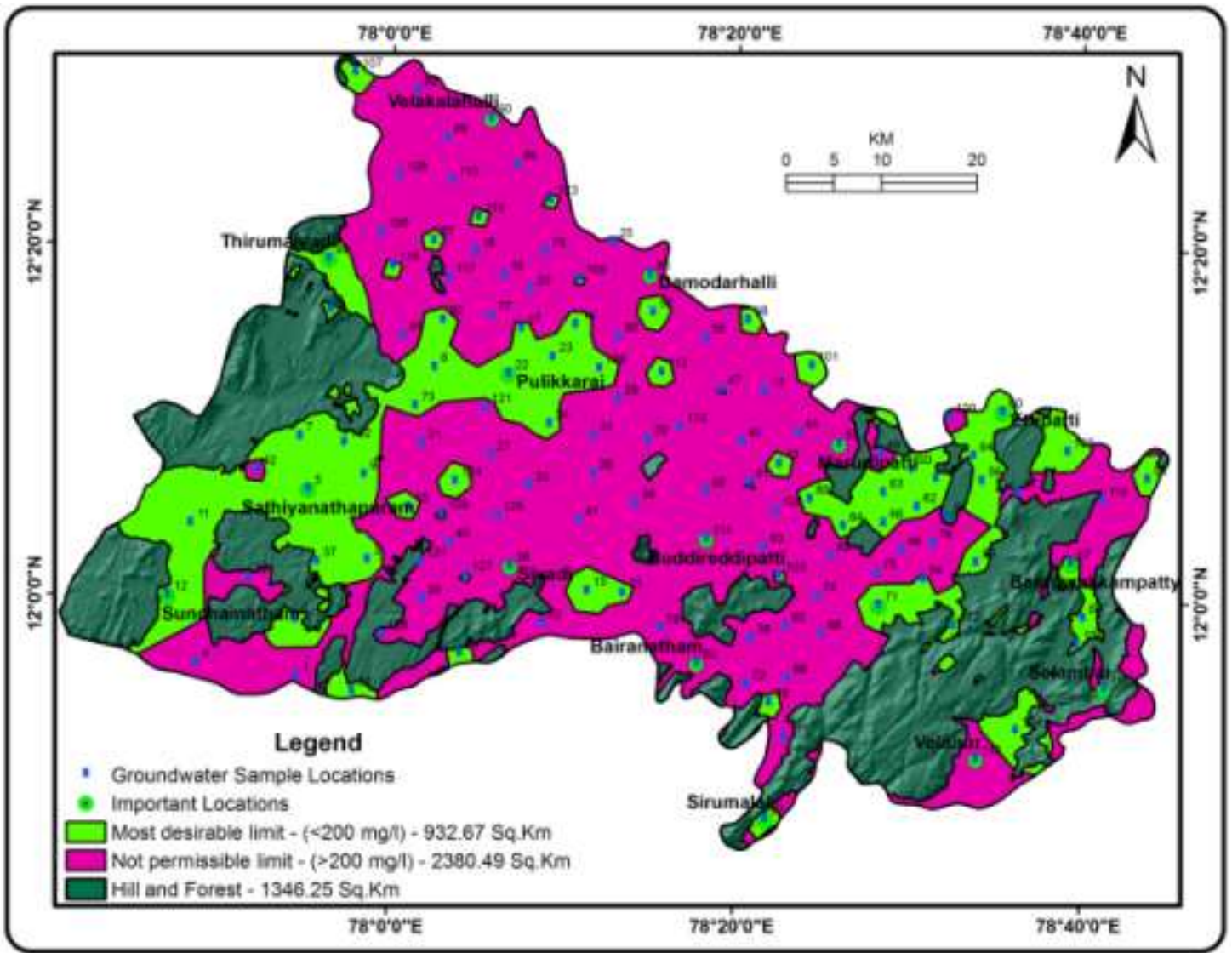

Fig. 4 Na Spatial Distribution Map

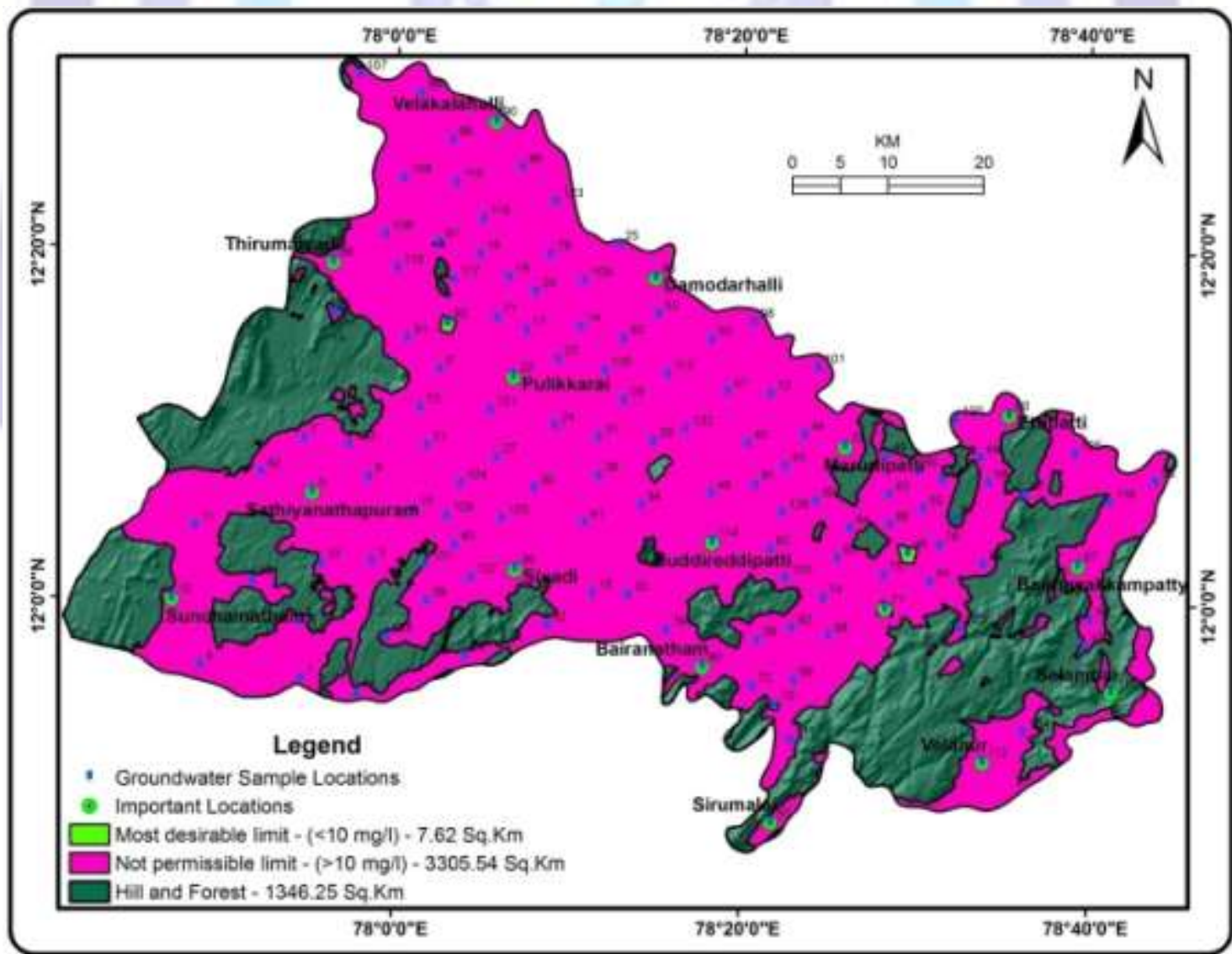

Fig. 5 K Spatial Distribution Map

4353 | P a g e 
ournal of Advances in Chemistry

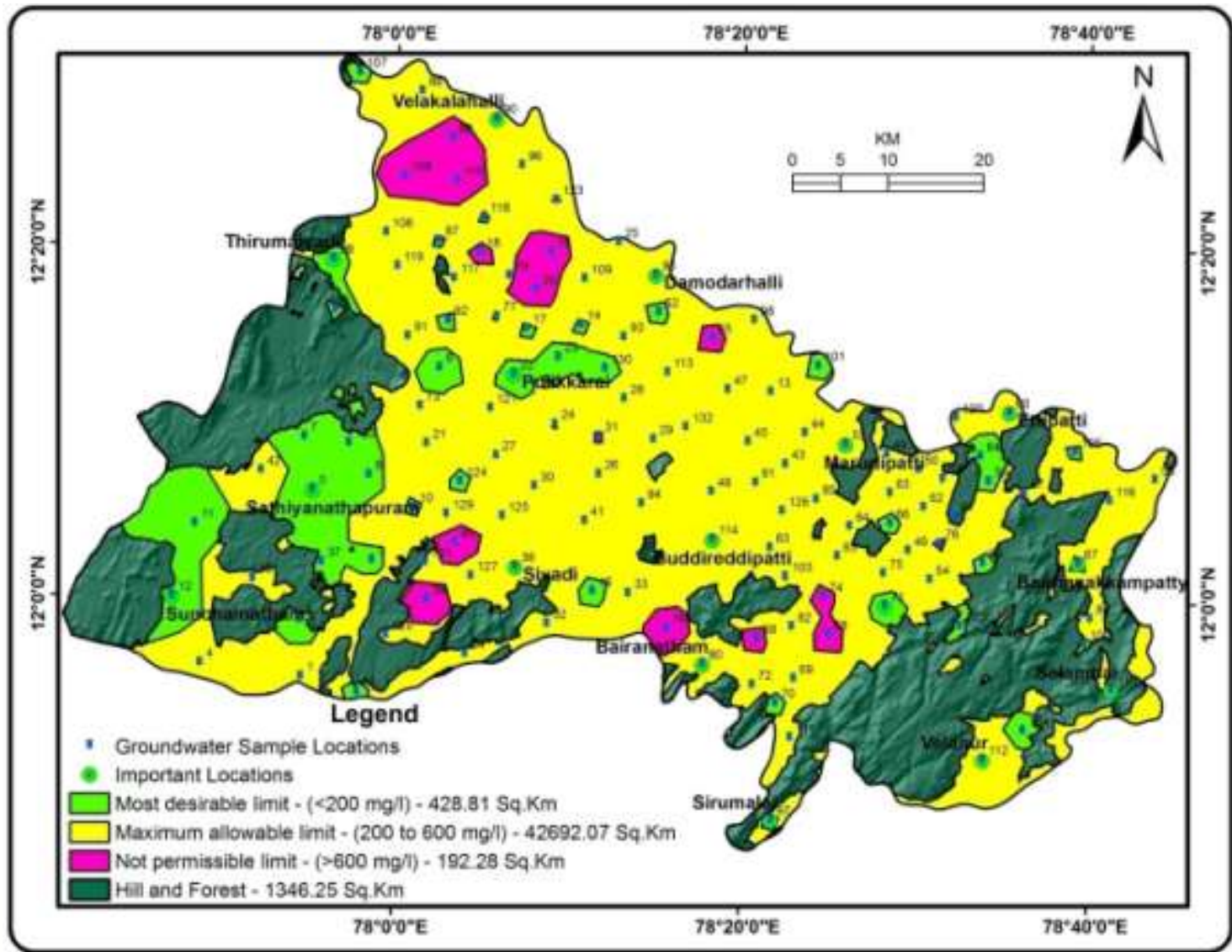

Fig. 6 Cl Spatial Distribution Map

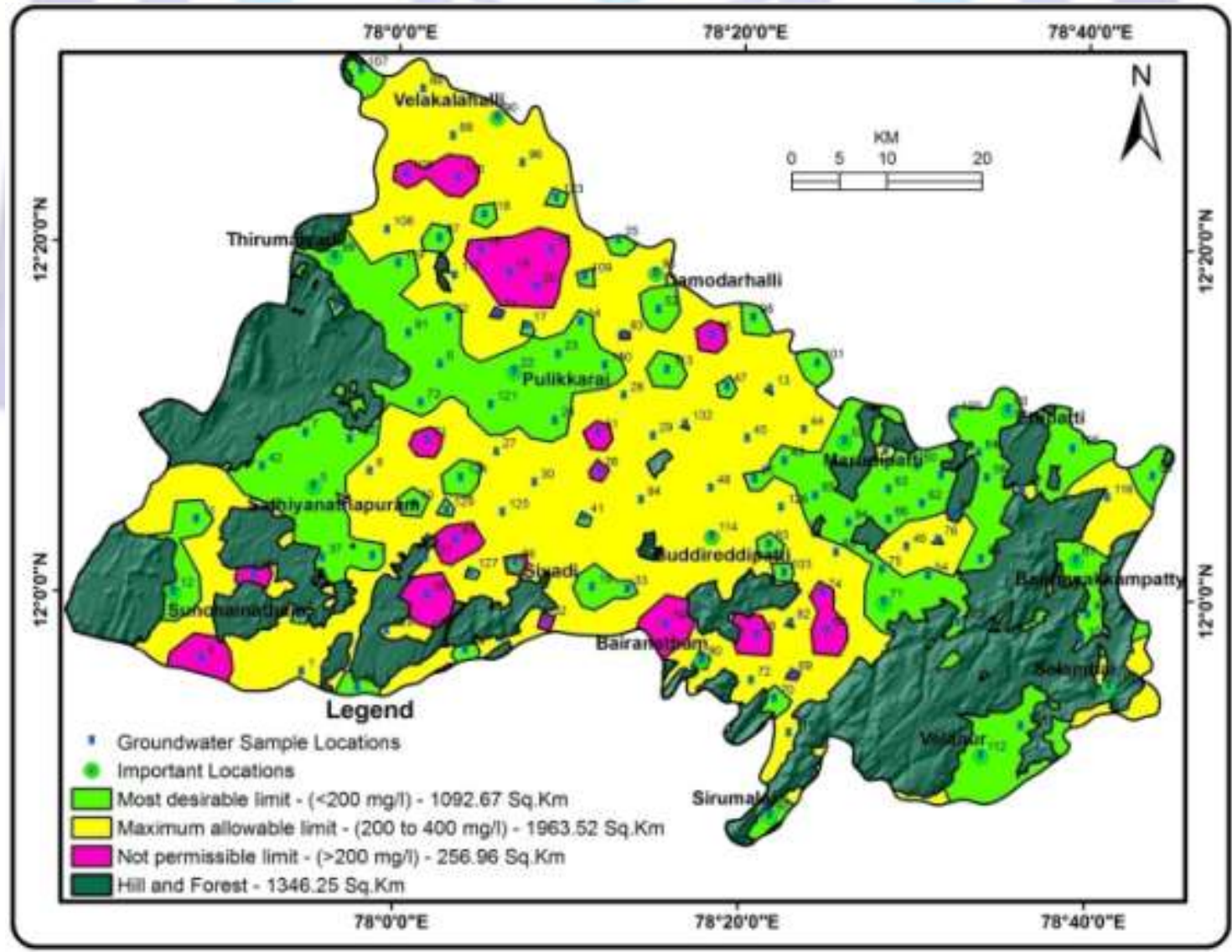

Fig. $7 \mathrm{SO}_{4}$ Spatial Distribution Map

4354 | P a g e 


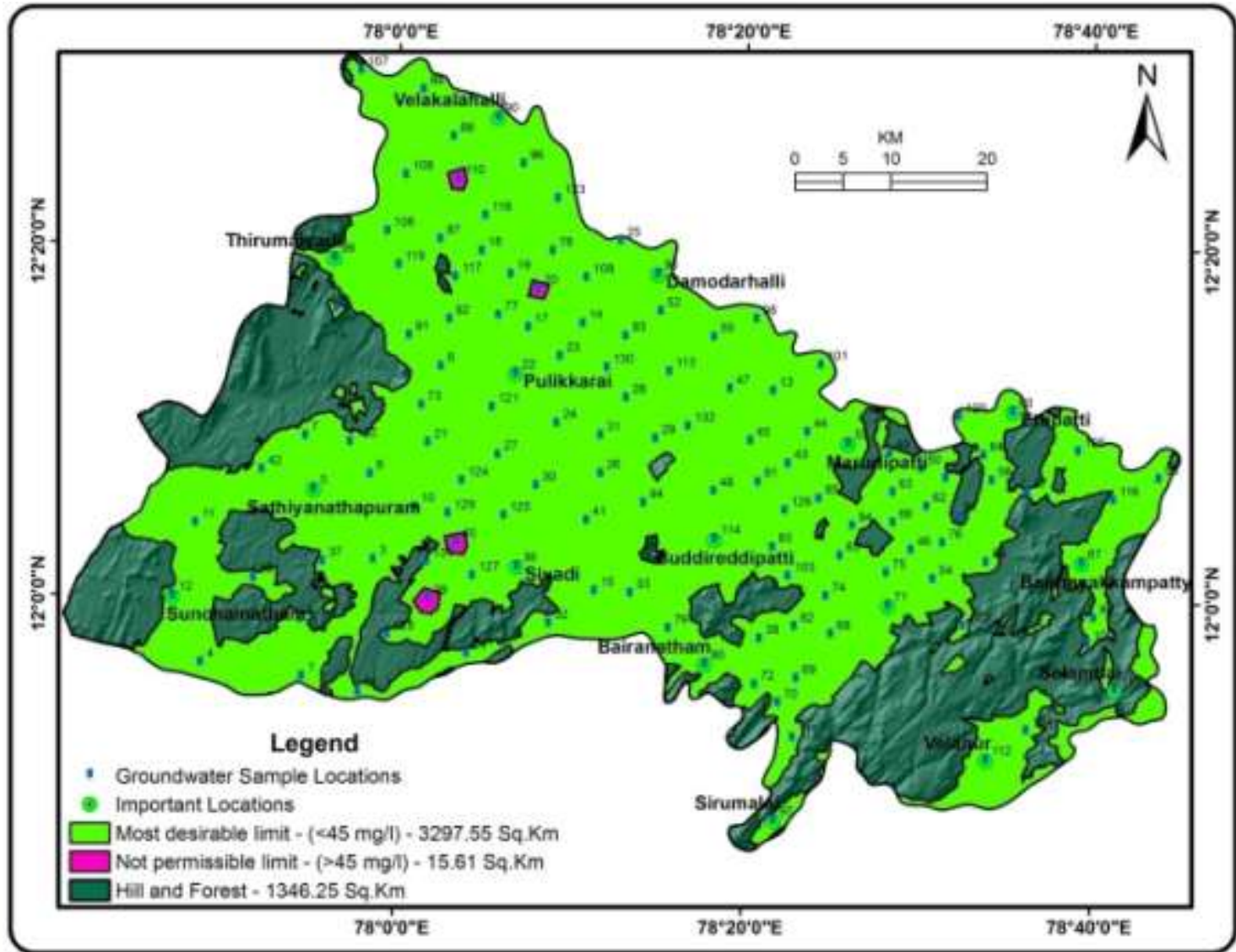

Fig. $8 \mathrm{NO}_{3}$ Spatial Distribution Map

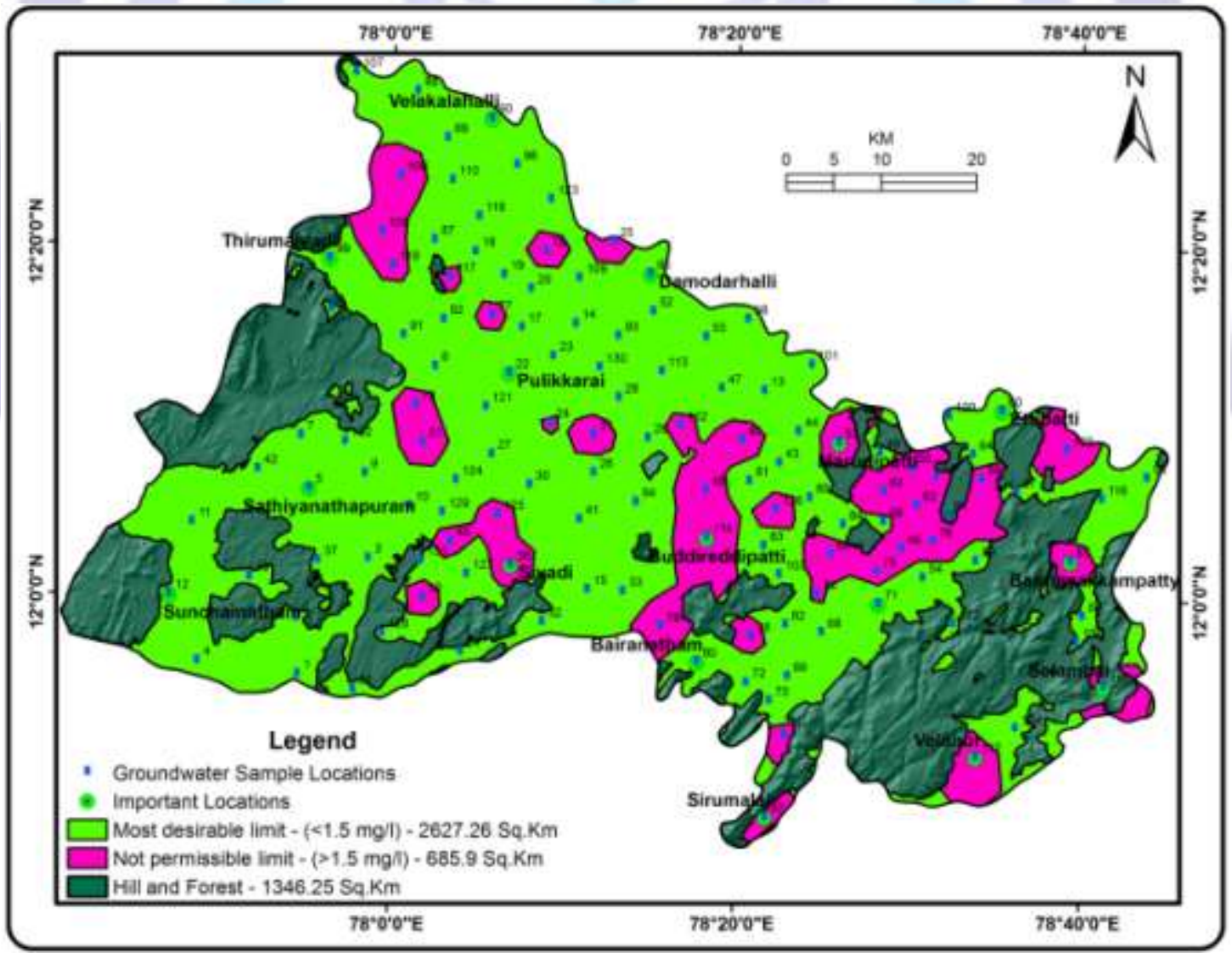

Fig. 9 F Spatial Distribution Map

4355 | P a g e 


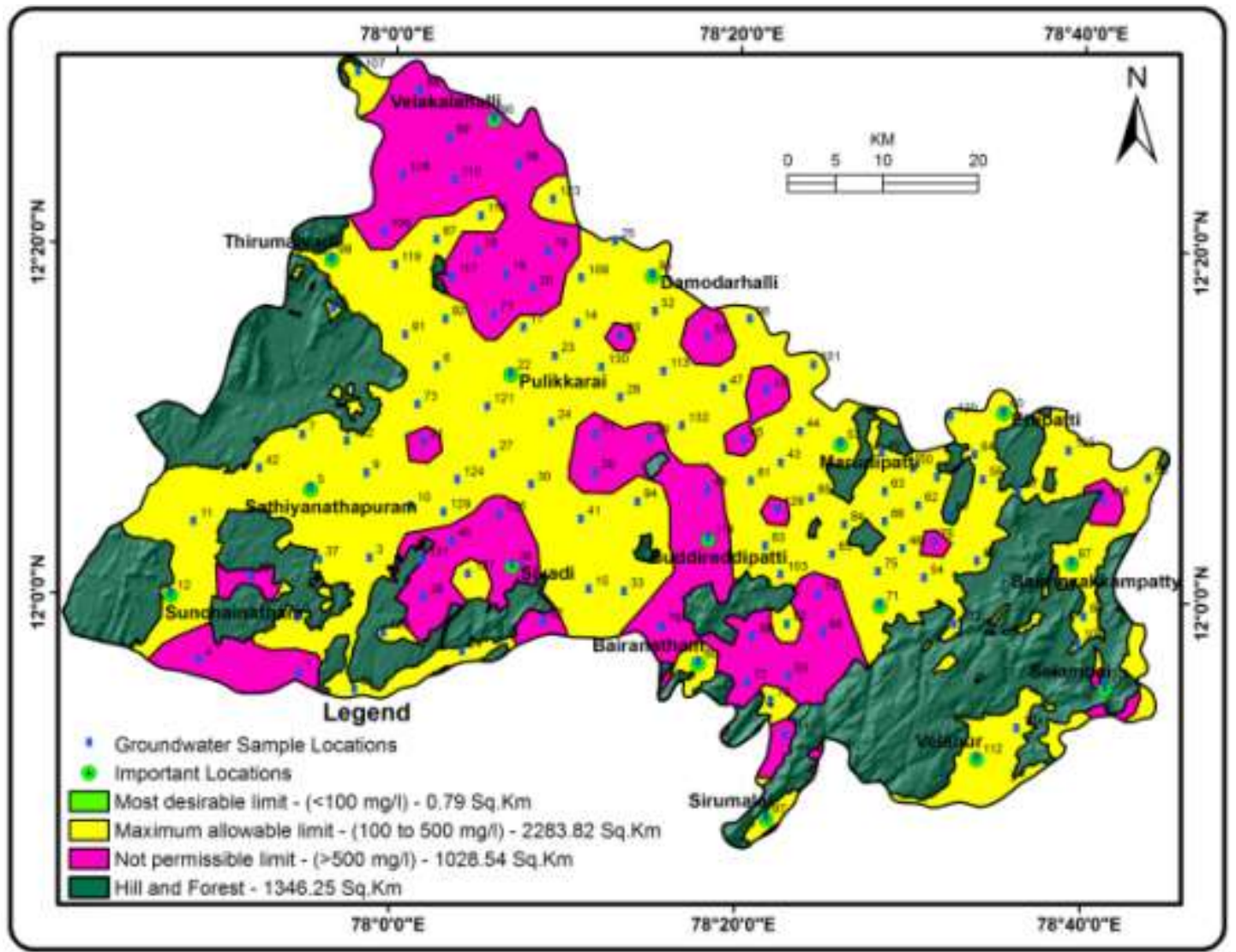

Fig. 10 TH Spatial Distribution Map

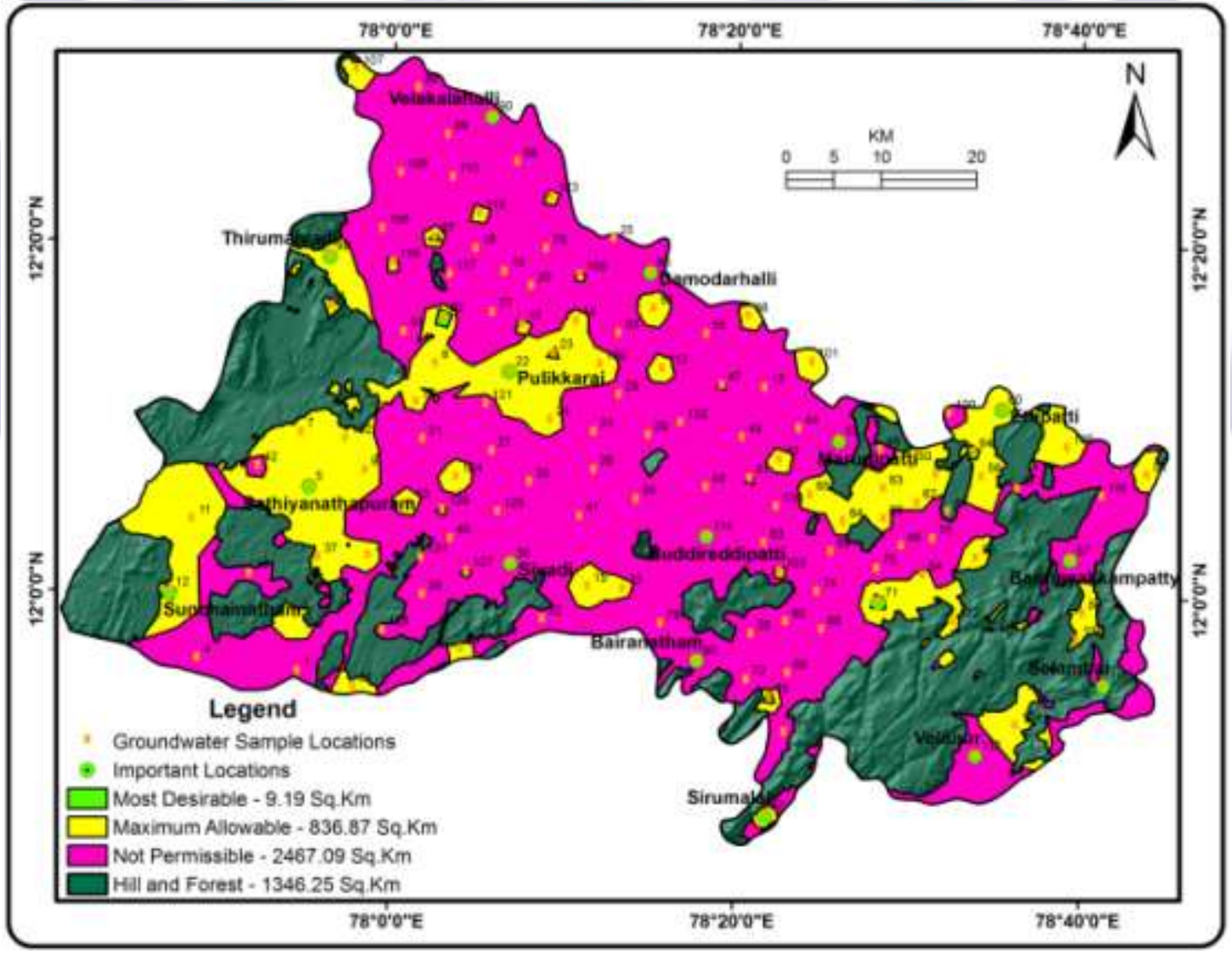

Fig. 11 Final Integration Water Quality Spatial Distribution Map 
Chloride is a less abundant constituent of the earth's crust but a major dissolved constituent of most natural waters. The chloride concentration varies between 56 and $1124 \mathrm{mg} / \mathrm{l}$ and average value $339.45 \mathrm{mg} / \mathrm{l}$ respectively. The high chloride concentration was noticed in only few locations. The chloride ions in drinking water are generally not harmful to human beings. Reason behind the high concentration of $\mathrm{Cl}$ improper wastes disposal (Kesavan et al., 2005). Cl spatial distribution map (Fig. 6) reveals that 192.28 Sq.Km areas are classified as not permissible limit.

The sulphate content of natural water is important in determining the suitability of water for residential use. Sulphur combines with oxygen to form the sulphate ion (SO4). The sulphate concentration in the groundwater during postmonsoon season ranged from 40 to $250.23 \mathrm{mg} / \mathrm{l}$, with an average value of $132 \mathrm{mg} / \mathrm{l}$. Sulphate is unstable, if it exceeds the most desirable limit of $400 \mathrm{mg} / \mathrm{l}$ and causes a laxative act on human system with the excess sulphate in groundwater (Bhagavathiperumal, 2008). Excess sulphate may cause cathartic action (Veerabadran et al., 2004). SO3 spatial distribution map (Fig. 7) reveals that $256.96 \mathrm{Sq} . \mathrm{Km}$ areas are classified as not permissible limit.

The nitrate concentration of groundwater samples ranged from 4 to $60 \mathrm{mg} / \mathrm{l}$, with an average value of $20.69 \mathrm{mg} / \mathrm{l}$. Nitrate is also an indicator of pollution. Nitrogen is fixed from the atmosphere and then mineralized by soil bacteria into ammonium and the aerobic conditions. The high concentration of nitrate in drinking water is toxic and causes blue baby or methemoglobinemia disease in children and gastric carcinomas. Nitrate is very loosely bound to the soil particles and easily leaches out and raises the groundwater level (Lalitha et al., 2004). NO3 spatial distribution map (Fig. 9) reveals that $15.61 \mathrm{Sq} . \mathrm{Km}$ areas are classified as not permissible limit. Fluoride is one of the chief trace elements in groundwater, which occurs as a natural constituent. Bedrock containing fluoride mineral is mainly responsible for high concentration of the ion in groundwater. The concentration of fluoride in groundwater of the study area varies from $0-2.80 \mathrm{mg} / \mathrm{l}$. Different forms of fluoride exposure affect the body's fluoride content increasing the risks of fluoride - prone diseases. Also fluoride has beneficial effects on teeth at low concentrations of $1 \mathrm{mg} / \mathrm{l}$ by avoiding the risk of tooth decay. $\mathrm{F}$ spatial distribution map (Fig. 9) reveals that $685.90 \mathrm{Sq} . \mathrm{Km}$ areas are classified as not permissible limit.

Total Hardness $(\mathrm{TH})$ represents the calcium and magnesium ions concentration. Because, these are the most polyvalent cations and other ions, such as iron, manganese contributes to the hardness of water and they are present in lower concentrations. The hardness of water is classified as hard and soft. The high total hardness value is termed as "hard", while water of low hardness values is termed as 'soft". The hardness value ranged from $76 \mathrm{mg} / \mathrm{l}$ to $968 \mathrm{mg} / \mathrm{l}$ with an average value of $425.53 \mathrm{mg} / \mathrm{l}$ respectively. TH spatial distribution map (Fig. 10) reveals that $1028.54 \mathrm{Sq} . \mathrm{Km}$ areas are classified as not permissible limit.

\section{SPATIAL ANALYSIS FOR DRINKING}

Thematic maps like TDS (Fig. 2), calcium (Fig. 3), sodium (Fig. 4), potassium (Fig. 5), chloride (Fig. 6), SO4 (Fig. 7), NO3 (Fig. 8), F (Fig. 9) and TH (Fig. 10) provides certain clues on for the quality of groundwater. In order to get all these informations unified, it is essential to integrate these data with appropriate factor. Therefore, numerically these informations are integrated through the application of GIS. The final (Drinking quality) map (Fig. 11) reveals that there are 3 combinations.

This methodology it is highly helpful in assessing the best groundwater quality zone. The following combinations suitable for domestic purpose "Not permissible" water quality zone cover about area 2467.09 Sq.Km respectively. While "Maximum allowable" water quality zone cover an area of $836.87 \mathrm{sq} . \mathrm{km}$. The "Most desirable" water quality zone an area $9.19 \mathrm{sq} . \mathrm{km}$ for drinking and domestic purposes.

\section{CONCLUSION}

The groundwater quality parameters in the study area with reference to the WHO standards were used to prepare the spatial distribution map. The final integrated map (Drinking quality) reveals the various parameters suitable for drinking purpose. "Not permissible" groundwater quality domains cover about area $2467 \mathrm{Sq} . \mathrm{Km}$ respectively. While "Maximum allowable" groundwater quality domains cover an about area $836.87 \mathrm{sq}$. km. The "Most desirable" water quality zone an area 9.19 sq.km for drinking and domestic purposes.

The physical appearance of the water is colorless which is also supported by the turbidity. The pH of the studied samples was almost neutral. The TDS and TH in 43 samples were very high and indicate that it is not suitable for drinking purpose. The $\mathrm{Ca} 2+$ concentration in most of the samples were within the WHO standards except 3 samples. The groundwater in 66 locations was not permissible for drinking with respect to $\mathrm{Na}+$, whereas $49 \%$ of the samples exceed the permissible limits of groundwater. The potassium concentration shows that, 123 sample falls in not permissible limits of potassium. Chloride and Sulphate results as 16 and 25 samples were fell in not permissible for drinking purposes.

\section{REFERENCES}

1. APHA (1995) Standard methods for the examination of water and waste water, 19th edn. APHA,Washington, DC.

2. Aravindan S, Manivel M, Chandrasekar SVN (2004) Ground water quality in the hard rack area of the Gadilam river basin, Tamil Nadu. J GeolSoc India 63(6):625-635

3. Adhikary PP, Dash CJ, Chandrasekharan H, Rajput TBS, Dubey SK (2012) Evaluation of groundwater quality for irrigation and drinking using GIS and geostatistics in a peri-urban area of Delhi, India. Arab J Geosci 5:14231434 
4. Aravindan S, Shankar K, Poovalinga Ganesh B, DharaniRajan K (2010) Hydrogeochemical mapping of in the hard rock area of Gadilam River basin, using GIS technique, Tamil Nadu. Indian J ApplGeochem 12(2):209-216

5. Bhagavathiperumal, S. and Thamarai, P. (2008) Ground water quality after Tsunami in coastal area of Kanyakumari, South Tamil Nadu, India. Int. Jour. Environ Sci. (eds.), v.2, no.2, pp. 99-118.

6. Gupta S, Nayek S, Chakraborty D (2016) Hydrochemical evaluation of Rangitriver, Sikkim, India: using Water Quality Index and multivariate statistics. Environ Earth Sci (2016) 75:567 DOI: 10.1007/s12665-015-5223-8

7. Gurugnanam B, Suresh M, Vinoth M, Prabhakaran N, Kumaravel S(2009) GIS based microlevel approach for hydrogeochemical studies in upper Manimuktha sub basin, Vellar, South India. Indian J. Sci. Technol. 2: 5-10.

8. Kumar M, Kumari K, Ramanathan A L and Saxena R 2007 A comparative evaluation of groundwater suitabil- ity for irrigation and drinking purposes in two intensively cultivated districts of Punjab, India; Environ. Geol. 53: 553574

9. Krishna Kumar S, Logeshkumaran A, Magesh NS, Godson Prince S, Chandrasekar N (2015) Hydrogeochemistry and application of water quality index (WQI) for groundwater quality assessment, Anna Nagar, part of Chennai City, Tamil Nadu, India. Appl Water Sci (2015) 5:335-343 DOI 10.1007/s13201-014-0196-4

10. Kesavan, K.G. and Parameswari, R. (2005) Evaluation of groundwater quality in Kancheepuram. Indian jour. of environmental protection, v. 25, no. 3, pp. 235-239.

11. Lalitha, S., Kalaivani, D., Selvameena, R. and Barani, A.V. (2004) Assay on quality of water samples from medical college area in Thanjavur, India. Jour. of environmental protection, v. 24, no. 12, pp. 925-930.

12. Prasanna, MV, Chidambaram S, \&Srinivasamoorthy K (2010) Statistical analysis of the hydrogeo- chemical evolution of groundwater in hard and sedimentary aquifers system of Gadilam river basin, South India. Journal of King Saud University Science, 22(3), 133-145.Raghunath HM (1987) Groundwater. New Delhi,Wiley Eastern Ltd, p 563

13. Singh DF (1992). Studies on the water quality index of some major rivers of Pune, Maharashtra. Proceedings of the Academy of Environmental Biology, 1(1): 61-66.

14. Subramani, T., Elango, L., \& Damodarasamy, S.R. (2005). Groundwater quality and its suitability for drinking and agricultural use Chithar River Basin, Tamil Nadu, India. Environ. Geol. 47, 1009-1110

15. Subba Rao N (2006) Seasonal variation of groundwater quality in a part of Guntur district, Andhra Pradesh, India. Environ Geol 49:413-429

16. Tiwari AK, Singh AK (2014) Hydrogeochemical Investigation and Groundwater Quality Assessment of Pratapgarh District, Uttar Pradesh. J GeolSoc India 83:329-343

17. Veerabadran, K., Ravichandra, M. and Prashanthi, M. (2004) Evaluation of water quality index at Vishakhapatnam city, Andhra Pradesh. Nature environment and pollution technology, v. 3, no. 1, pp. 65-68.

18. WHO. (1996). Guideline for drinking water quality. Vol.2, Health criteria and other supporting information, WHO, Geneva. 973. 